\title{
Lack of Secondary Transmission of Ebola Virus from Healthcare Worker to 238 Contacts, United Kingdom, December 2014
}

\author{
Paul Crook, Alison Smith-Palmer, Helen Maguire, \\ Noel McCarthy, Hilary Kirkbride, Bruce Court, \\ Sanch Kanagarajah, Deborah Turbitt, Syed \\ Ahmed, Paul Cosford, Isabel Oliver
}

In December 2014, Ebola virus disease (EVD) was diagnosed in a healthcare worker in the United Kingdom after the worker returned from an Ebola treatment center in Sierra Leone. The worker flew on 2 flights during the early stages of disease. Follow-up of 238 contacts showed no evidence of secondary transmission of Ebola virus.

$\mathrm{M}$ ore than 28,000 cases of Ebola virus disease (EVD) were reported during the epidemic in West Africa in 2014-2015 (1). International healthcare workers (HCWs) responded, and a number subsequently became infected with EVD, including those given a diagnosis after their return travel (2). There is international guidance for followup of aircraft contacts of case-patients with EVD (3-5).

We report contact tracing after EVD was diagnosed in an HCW in the United Kingdom who had worked in an Ebola treatment center in Sierra Leone. This worker had become ill while traveling back to the United Kingdom via Morocco.

\section{The Study}

For this investigation, a multiagency incident control team and contact tracing teams were established with staff of Public Health England (PHE) and Health Protection Scotland. We undertook a risk assessment that included interviewing the case-patient about symptoms, travel, and contacts. We used preexisting guidance (6) to classify contacts according to their degree of exposure to the case-patient and to other persons with EVD on the basis of the degree of infectiousness and physical contact (Table). The degree of public health follow-up of contacts was formulated according to their exposure category (Table).

We asked airlines to provide passenger manifests; advanced passenger information (nationality, passport

Author affiliations: Public Health England, London, UK

(P. Crook, H. Maguire, N. McCarthy, H. Kirkbride, B. Court,

S. Kanagarajah, D. Turbitt, P. Cosford, I. Oliver); Health Protection

Scotland, Glasgow, Scotland, UK (A. Smith-Palmer, S. Ahmed);

University College London, London ( $\mathrm{H}$. Maguire)

DOI: https://doi.org/10.3201/eid2312.171100 numbers, date of birth); and contact details. If contact details were missing or incorrect, we sought additional information from Her Majesty's Passport Office, the UK Border Agency, PHE port entry screening and returning workers information, the National Health Service Patient Demographic Service, and online social networks. For contacts with UK addresses, we conducted a home visit if telephone contact was unsuccessful. For foreign national contacts, PHE also contacted the National Focal Point of the relevant country as per International Health Regulations. Public helplines were established to provide a contact point for those potentially affected. PHE provided public health advice to United Kingdom airline staff, and Moroccan authorities provided public health advice to Morocco airline staff. Moroccan authorities led contact tracing for the flight to Morocco, which is not reported in this article.

The case-patient was a UK national HCW who had worked in an Ebola treatment center in Sierra Leone and had direct patient contact. On December 28, 2014, she flew from Sierra Leone to Glasgow on 3 flights and 2 aircraft of 2 airlines: from Freetown, Sierra Leone, to Casablanca, Morocco (3 h, $40 \mathrm{~min}$ ); Casablanca to London, England ( 3 h, $30 \mathrm{~min}$ ); and London to Glasgow, Scotland (1 h, $20 \mathrm{~min}$ ).

During exit screening before boarding in Freetown and Casablanca, the case-patient was reported to have been apyrexial. Symptoms of fever and malaise began during the Casablanca to London flight. At London Heathrow Airport, several readings of temperatures $<37.6^{\circ} \mathrm{C}$ were made by screening staff before onward travel. In Glasgow, after the case-patient took a taxi home, her symptoms worsened, and she telephoned local health services. The case-patient did not report vomiting, diarrhea, or bleeding before diagnosis and admission. Contacts had not been exposed to body fluids.

The case-patient was admitted to a hospital in Glasgow and given a diagnosis of EVD on December 29, 2014. The patient was subsequently transferred by military plane to a specialist infectious diseases hospital in London on December 30, 2014. She survived her illness.

Aircraft passengers in the same seat row and 2 rows in front of and behind the case-patient were classified as category 2 contacts. All other passengers and crew were classified as category 1 contacts. Border Force staff, health 
Table. Characteristics of 238 contacts of a healthcare worker with Ebola virus disease and summary of public health action, by category, United Kingdom, December 2014*

\begin{tabular}{|c|c|c|c|c|}
\hline \multirow[b]{2}{*}{ Characteristic } & \multicolumn{3}{|c|}{ No. contacts by exposure category } & \multirow[b]{2}{*}{ Total } \\
\hline & 1; No direct contact & $\begin{array}{l}\text { 2; Direct contact with low } \\
\text { risk for exposure }\end{array}$ & $\begin{array}{l}\text { 3; Direct contact with high } \\
\text { risk for exposure }\end{array}$ & \\
\hline \multicolumn{5}{|l|}{ Exposure setting } \\
\hline Casablanca-LHR passengers & 109 & 23 & 0 & 132 \\
\hline Casablanca-LHR crew & 13 & 0 & 0 & 13 \\
\hline LHR PHE screeners & 4 & 0 & 0 & 4 \\
\hline LHR Border Force & 7 & 0 & 0 & 7 \\
\hline LHR-Glasgow passengers & 62 & 8 & 0 & 70 \\
\hline LHR-Glasgow crew & $7 \dagger$ & 0 & 0 & 7 \\
\hline Healthcare workers & $4 \ddagger$ & 0 & 0 & 4 \\
\hline Glasgow community & 0 & 1 & 0 & 1 \\
\hline Total§ & 185 & 24 & 29ा & 238 \\
\hline Summary of public health action & $\begin{array}{l}\text { Risk assessment } \\
\text { questionnaire completed; } \\
\text { provided telephone advice } \\
\text { on symptoms of EVD; } \\
\text { action to take if they had } \\
\text { fever or symptoms } \\
\text { consistent with EVD in the } \\
21 \text { d after their most recent } \\
\text { exposure; advised that there } \\
\text { was no reason to stop their } \\
\text { day-to-day activities during } \\
\text { the surveillance period } \\
\text { provided they remained well; } \\
\text { advised that their family and } \\
\text { household contacts were not } \\
\text { at risk for EVD if contact } \\
\text { remained asymptomatic }\end{array}$ & $\begin{array}{l}\text { As for category } 1 \text { plus } \\
\text { provided written advice and } \\
\text { a temperature monitoring } \\
\text { kit, advised to take their } \\
\text { temperature twice a day } \\
\text { and to contact the local } \\
\text { public health team if they } \\
\text { had a fever or symptoms } \\
\text { consistent with EVD in the } \\
21 \text { d after their most recent } \\
\text { exposure; advised to delay } \\
\text { any nonessential } \\
\text { healthcare treatment until } \\
\text { after the } 21 \text {-d period; local } \\
\text { public health teams } \\
\text { assessed the contact after } \\
21 \mathrm{~d} \text { and reported their } \\
\text { completion of public health } \\
\text { follow-up }\end{array}$ & $\begin{array}{l}\text { As for category } 2 \text { plus } \\
\text { required to contact the } \\
\text { local public health team } \\
\text { daily to report their } \\
\text { temperature and advised } \\
\text { not to undertake healthcare } \\
\text { activity; if contact was not } \\
\text { made, the local public } \\
\text { health team contacted } \\
\text { them }\end{array}$ & NA \\
\hline
\end{tabular}

*In England a home visit was attempted if no telephone contact was possible. EVD, Ebola virus disease; LHR, London Heathrow Airport; NA, not applicable; PHE, Public Health England.

†Includes 3 cabin staff and 4 land customer services staff.

łIncludes 2 doctors and 2 nurses who provided dedicated care to the patient while in the specialist infectious diseases unit.

$\S$ Reflects overall number of persons categorized according to their highest category, including those categorized because of their healthcare work contact in Sierra Leone. Numbers in each category do not represent a sum of a column.

\29 contacts who flew Casablanca-LHR were classified as category 3 because of their healthcare-related activity in West Africa.

screeners, and HCWs were classified as category 1 contacts, and a community contact was classified as a category 2 contact (Table).

A total of 238 persons, including 185 category 1 contacts and 24 category 2 contacts, were assessed as having sufficient exposure to the case-patient to warrant further public health follow-up (Table). Although no contacts were classified as being category 3 (direct contact with high exposure risk) because of exposure to the case-patient, 29 contacts were classified as category 3 because of other Ebola exposures, including healthcare work in Sierra Leone.

All 16 non-flight-related contacts were successfully followed up. Passengers on the Casablanca to London flight represented 17 nationalities, and 59 (45\%) of 132 had non-UK passports. We successfully contacted all passengers on both flights, except for 3 category 1 passengers who had non-UK passports (199/202, 99\%); a total of 162 $(80 \%)$ passengers were contacted within $48 \mathrm{~h}$ of diagnosis for the case-patient.

We provided information for the 3 passengers we could not contact to their respective countries through their
National Focal Point. Two persons in the United Kingdom required home visits. All flight crew were contacted. No additional cases of EVD were identified among contacts.

\section{Conclusions}

A precautionary approach was taken regarding contacts on the aircraft, wider than international guidance recommends (one seat in either direction of the case-patient) (3-5) but consistent with the response to a case diagnosed in the United States (10). The case-patient we report was probably in the early stages of illness, and there was no evidence of high-risk exposure to body fluids on board the aircraft.

A precautionary approach was taken regarding classification of contacts on the aircraft. We used a wider definition for the closest contact category than that recommended by international guidance ( 1 seat in either direction of the case-patient) (3-5) but consistent with that used for the response to a case diagnosed in the United States (10). The decision to contact all persons on the affected aircraft was taken to inform and reassure contacts, not just to prevent transmission. 
The limited information on passengers initially available hampered the ability to make contact promptly and resulted in extensive efforts to trace persons. Furthermore, flight manifests included passengers who had not flown. Issues with flight information have arisen before in the United Kingdom related to contact tracing (11). The need for airlines to collect personal rather than agency contact details should be stressed. To ensure a rapid response, public health agencies need to work with airlines and other international organizations to ensure access to a minimum dataset that would support rapid notification of contacts. In the United Kingdom, the National Health Service Patient Demographic Service was essential for obtaining contact details and identifying whether contacts were likely to be UK residents. In addition, the Ebola port entry screening and returning workers scheme provided rapid information on 37 contacts whose journey originated in Ebola-affected countries.

Temperature screening while the case-patient transferred through Heathrow Airport did not confirm fever, and the patient was allowed to continue the journey. In the presence of exit screening, airport entry screening might not detect imported EVD $(12,13)$. However, one purpose of this screening has been to ensure that persons receive information to enable them to seek care quickly and in a manner that helps prevent transmission. Advice provided during airport screening and healthcare deployments aims to ensure that when symptoms develop, exposed persons contact health services early and by telephone, enabling responders to take appropriate measures to reduce transmission. In this instance, early contact with health services resulted in only a small number of contacts outside the flights. An evaluation of EVD port entry screening and a scheme for returning workers in the United Kingdom is under way.

This study provides support for the conclusion that there is low risk for transmission of Ebola virus on aircraft from EVD case-patients in the early stages of disease. Providing information and advice to contacts can be a helpful public health intervention in minimizing virus transmission.

\section{Acknowledgments}

We thank the staff at the Royal Free London National Health Service Foundation Trust for case-patient interviewing; National Incident Control Team members, including Gina Radford and Jill Meara, and Health Protection Scotland staff; PHE Centre Health Protection teams, including Sara Atkin; PHE Field Epidemiology Service teams; the PHE Centre for Chemicals Radiation and Environmental Hazards; the PHE Centre for Infectious Disease Surveillance and Control, including Carol Chatt; the PHE International Health Regulations team, including Jane Jones, Joanne Freedman, and Gemma Smith; and Public Health Wales, including Chris Williams, for coordination and support with contact tracing; the PHE Ebola Guidance Cell for advice on contact tracing; Keith Neal for liaison with screening teams; Piers Mook for database coordination; PHE Ebola screening and returning workers, including Mark Driver and Tanya Semple, for liaison with airlines; the PHE Emergency Response Department for coordination and establishing a help line; and Moroccan and other international public health authorities for support with airline staff and passenger contact tracing.

Dr. Crook is a consultant epidemiologist in the Field Epidemiology Service of Public Health England, London, UK. His research interests are outbreak response and epidemiology of sexually transmitted infections and HIV infections, including shigellosis in men who have sex with men.

\section{References}

1. World Health Organization. Ebola situation report, March 20, 2016 [cited 2017 Sep 14]. http://apps.who.int/ebola/current-situation/ ebola-situation-report-30-march-2016

2. Petti S, Protano C, Messano GA, Scully C. Ebola virus infection among western healthcare workers unable to recall the transmission route. Biomed Res Int. 2016;2016:8054709. Epub 2016 Nov 27. http://dx.doi.org/10.1155/2016/8054709

3. Leitmeyer K. European risk assessment guidance for infectious diseases transmitted on aircraft - the RAGIDA project. Euro Surveill. 2011;16:19845.

4. Gilsdorf A, Morgan D, Leitmeyer K. Guidance for contact tracing of cases of Lassa fever, Ebola or Marburg haemorrhagic fever on an airplane: results of a European expert consultation. BMC Public Health. 2012;12:1014. http://dx.doi.org/10.1186/ 1471-2458-12-1014

5. World Health Organization. Travel and transport risk assessment: interim guidance for public health authorities and the transport sector, 2014 [cited 2017 Sep 14]. http://apps.who.int/iris/bitstream/10665/ 132168/1/WHO_EVD_Guidance_TravelTransportRisk_14.1_eng.pdf

6. Advisory Committee on Dangerous Pathogens Public Health England. Management of hazard group 4 viral haemorrhagic fevers and similar human infectious diseases of high consequence, November 2015 [cited 2017 Sep 14]. http://www.nric.org.uk/ node $/ 54189$

7. Formenty P, Hatz C, Le Guenno B, Stoll A, Rogenmoser P, Widmer A. Human infection due to Ebola virus, subtype Côte d'Ivoire: clinical and biologic presentation. J Infect Dis. 1999;179(Suppl 1):S48-53. http://dx.doi.org/10.1086/514285

8. Shuaib F, Gunnala R, Musa EO, Mahoney FJ, Oguntimehin O, Nguku PM, et al.; Centers for Disease Control and Prevention (CDC). Ebola virus disease outbreak-Nigeria, July-September 2014. MMWR Morb Mortal Wkly Rep. 2014;63:867-72.

9. Fasina FO, Shittu A, Lazarus D, Tomori O, Simonsen L, Viboud C, et al. Transmission dynamics and control of Ebola virus disease outbreak in Nigeria, July to September 2014. Euro Surveill. 2014;19:20920. http://dx.doi.org/10.2807/1560-7917. ES2014.19.40.20920

10. Regan JJ, Jungerman R, Montiel SH, Newsome K, Objio T, Washburn F, et al.; Centers for Disease Control and Prevention (CDC). Public health response to commercial airline travel of a person with Ebola virus infection-United States, 2014. MMWR Morb Mortal Wkly Rep. 2015;64:63-6.

11. Parry-Ford F, Boddington N, Pebody R, Phin N, on behalf of the Incident Managemen C; Incident Management Team. Public health response to two incidents of confirmed MERS-CoV cases travelling on flights through London Heathrow Airport in 2014: lessons learnt. Euro Surveill. 2015;20:21114. http://dx.doi.org/10.2807/1560-7917.ES2015.20.18.21114 
12. Mabey D, Flasche S, Edmunds WJ. Airport screening for Ebola. BMJ. 2014;349:g6202. http://dx.doi.org/10.1136/ bmj.g6202

13. Cosford P. Advantages of airport screening for Ebola. BMJ. 2014;349:g6585. http://dx.doi.org/10.1136/bmj.g6585
Service, Public Health England, Skipton House, 80 London Rd, London SE16LH, UK; email: paul.crook@phe.gov.uk

Address for correspondence: Paul Crook, Field Epidemiology

\section{May 2013: Zoonoses}

- Transmission of Mycobacterium tuberculosis Beijing Strains, Alberta, Canada, 1991-2007

- Foodborne Transmission of Bovine Spongiform Encephalopathy to Nonhuman Primates

- Populations at Risk for Alveolar Echinococcosis, France

- WHO International Standard to Harmonize Assays for Detection of Hepatitis E Virus RNA

- Full-Genome Deep Sequencing and Phylogenetic Analysis of Novel Human Betacoronavirus

- Targeting Surveillance for Zoonotic Virus Discovery

- Changes in Severity of Influenza A(H1N1)pdm09 Infection from Pandemic to First Postpandemic Season, Germany

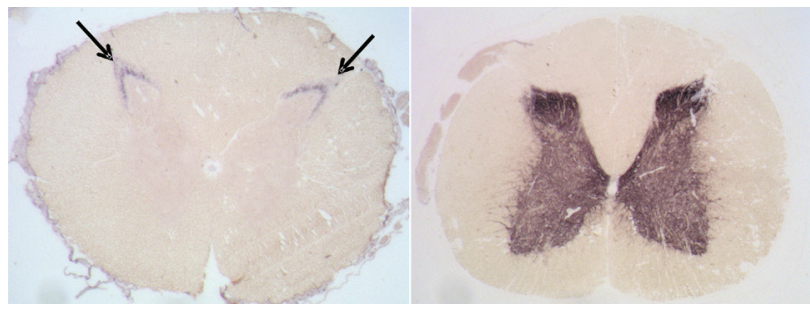

- Severe Fever with Thrombocytopenia Syndrome Virus among Domesticated Animals, China

- Campylobacter coli Outbreak among Men Who Have Sex with Men, Quebec, Canada, 2010-2011

- Delayed Diagnosis of Chronic Q Fever and Cardiac Valve Surgery

- Treatment of Tularemia in Patient with Chronic Graftversus-Host Disease

- Scrub Typhus Outbreak, Northern Thailand, 2006-2007

- Rickettsia parkeri Infection Detected from Eschar Swab Specimens

- Contaminated Ventilator Air Flow Sensor and Bacillus cereus Colonization of Newborns

- Mapping Environmental Suitability for Malaria Transmission, Greece

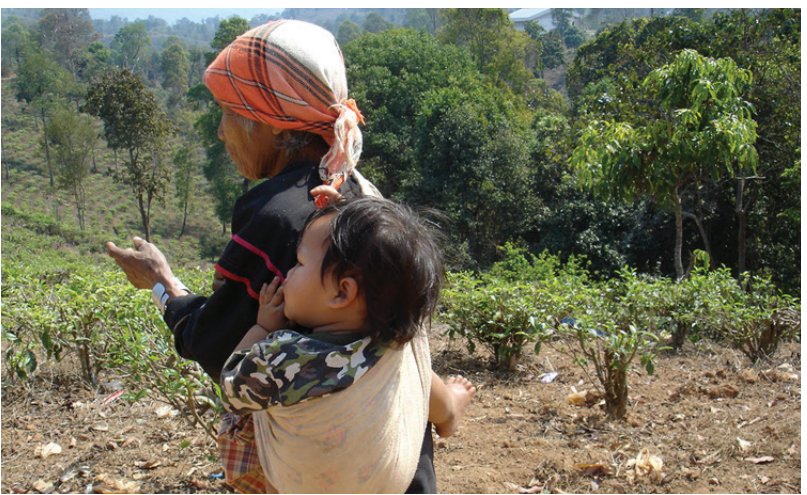

- Implications of Dengue Outbreaks for Blood Supply, Australia

- Novel Molecular Type of Clostridium difficile in Neonatal Pigs, Western Australia

- Novel Lyssavirus in Bat, Spain

- Borrelia recurrentis in Head Lice, Ethiopia

- Tuberculosis Exposure among Evacuees at a Shelter after Earthquake, Japan, 2011

- Primaquine Tolerance in Patient with Relapsing Vivax Malaria

- Tickborne Encephalitis Associated with Consumption of Raw Goat Milk, Slovenia, 2012

- Spread of Multidrug-Resistant Acinetobacter baumannii Clone, France

- Plasmodium falciparum with Multidrug Resistance 1 Gene Duplications, Senegal

- Atypical Erythema Migrans in PCR-Positive Lyme Disease

- Brucellosis in Guangdong Province, People's Republic of China, 2005-2010

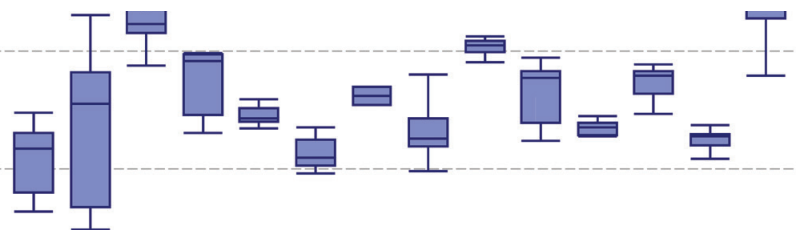

